\title{
Chapter 6 Water Governance: A Systemic Approach
}

\author{
Petra Dobner and Hans-Georg Frede
}

\begin{abstract}
The article investigates the contributions of system theory and governance literature to implementing and managing MEWPs. Both approaches share the belief that problems should be addressed holistically and thus challenge the division of labor in the water sector. After sketching some major characteristics of system theory and governance, the findings are applied to MEWPs in Fergana and Jordan.
\end{abstract}

Keywords Governance $\bullet$ Millennium development goals $\bullet$ System theory $\bullet$ Major water engineering projects $\bullet$ Institutions $\bullet$ Public participation $\bullet$ Complexity $\bullet$ Soviet Union $\bullet$ Legacy $\bullet$ Fergana Valley $\bullet$ Red Sea $\bullet$ Dead Sea Project

\subsection{Introduction}

All commonplaces about water share the conviction that water is universal and essential. Water is life, indeed, and the availability of and access to water is of utmost concern for every organism and organization. Water issues are ubiquitous and all embracing. It is quite plausible to conclude that the technical and political management of water should be similarly comprehensive.

Quite contrary, though, is everyday practice. Typically, water issues are addressed from numerous partial standpoints. Technicians and engineers should solve infrastructural problems, natural scientists deliver information about the quality and availability of water, and political and social scientists are in charge of regulatory or social matters. This division of labour is neither peculiar nor surprising. Fragmented responsibilities seem a natural consequence of differentiation, segmentation, and specialization, the foremost features of modernity. The water sector is but one example of many for this dominant trend, but in this case the price is especially

\footnotetext{
P. Dobner $(\bowtie)$

Institute of Political Science and Japanese Studies, Martin-Luther-Universität

Halle-Wittenberg, Emil-Aberhalden-Str. 7, 06099 Halle/Saale, Germany

e-mail: petra.dobner@politik.uni-halle.de
}

H.-G. Frede

Institute of Landscape Ecology and Resource Management (ILR),

Justus-Liebig-Universität Gießen, Heinrich-Buff-Ring 26-32, 35392 Gießen, Germany 
high. Despite some progress, many parts of the world are constantly lagging behind the water-related Millennium Development Goals (MDGs) (United Nations 2006, $2007,2008,2009,2012)$ not to mention the minor advances made in the overarching goal of the UN Charta to guarantee access to drinking water and safe sanitation for everybody as a human right or, even more ambitious, establish water security for all individual, agronomic, and economic purposes. With good cause, there are doubts that various water sector goals can ever be achieved as long as both scientific knowledge about and practical management of water are dominated by specialization and distinction.

Major water engineering projects (MWEPs) can act as examples for studying the problems the water sector faces in general. MWEPs are conceived of "complex socio-technical, social-ecological and political-economic systems or configurations" (Moss and Dobner 2015, in this volume, pp. 101-111). Hence their scientific assessment and management has to address a number of different, but interdependent issues simultaneously. As evident as this basic insight into the challenges of sustainably managing MWEPs is, it remains difficult to meet these demands in theory and practice. That MWEPs' knowledge is created in separate realms put up barriers to ambitions to holistically bridge unique scientific languages, knowledge bases, and approaches. Practitioners usually are well aware of the complexity and interrelatedness of problems associated with the installation and management of MWEPs, but fragmented responsibilities for technical, ecological, or cultural and social issues frequently prevent coordinated action. For example, while a MWEP may be technically feasible and economically desirable, social, cultural, or political resistance can throw up insurmountable obstacles for a project's implementation and/or its maintenance.

Understanding and managing the complexity of MWEPs properly remains a scientific and practical aspiration. In the following section, we address this problem by first looking at two different approaches: System Theory (6.2) and Governance (6.3), which from different perspectives both promise to link the separate fields of science and practice. Secondly, by applying our findings to MWEPs, and finally by drawing some conclusions on further research (6.4).

\subsection{System Theory Revisited}

In the middle of the twentieth century, a number of scientists from heterogeneous disciplines promoted a holistic approach under the label of (General) System Theory (see von Bertalanffy 1950). Taking on ideas from cybernetics, i.e. a scientific stream dealing with regulation and control of machines, living organisms and social organizations (Wiener 1948), system theory centres around the notion that any "complex of interacting elements" (von Bertalanffy 1950, p. 143) can be defined as a "system." A system is, therefore, any social, biological, technical, political, economic, psychological, or other kind of entity that consists of a number of connected parts. It is important to note that system theory also operates with the similarly abstract 
notion of "environment" to describe the fact that systems have borders and (usually) interact with and are influenced by their surroundings. Obvious differences between mice and men, organisms and organizations are deliberately neglected for the benefit of discovering general laws, abstract similarities, and analytical analogies.

System theory thus considers a country as a system as well as a large dam, or any other kind of MWEP. They are embedded in a specific environment, e.g. neighboring countries or the political and geographical circumstances they are placed in. By applying this general analytic framework on all kinds of objects, the theory claims that irrespective of their nature, systems are characterised by common features: foremost, the systemic view is fuelled by the conviction that "the operation of no one part can be fully understood without reference to the way in which the whole itself operates" (Easton 1957; see Easton 1965) and that, vice versa, the system in general depends on the interaction of all its parts. This view of a system and its elements is substantiated by further ideas about the ways the elements and the system are connected with each other and how they are embedded in their environment. Attention is directed to the complexity, i.e. the number of relations between the elements of a system as well as to its relations to its environment (Hill et al 1994, p. 22f.). The dynamic of a system is expressed as the intensity of changes the system undergoes in a certain amount of time. By stressing the complexity and dynamics of both the system and its environment, system theory also rejects simplified ideas about causes and effects and enhances the idea of multiple interdependencies instead. Advocates of system theory also point out the fact that isomorphic laws such as the law of exponential growth - operate in as differing fields as e.g. biology and sociology. System theory should therefore enable methodological advancements throughout different scientific fields as "an important means of controlling and instigating the transfer of principles from one field to another" (von Bertalanffy 1950, p. 142).

With its core concern of understanding the wholeness of something (i.e. any "system") in terms of the interaction, interrelatedness, and interdependence of all its components within a changing environment, system theory seems to be well capable of addressing generally acknowledged growing complexities; something which holds true in the field of water in general, and MWEPs in particular. Nonetheless, system theory findings cannot be easily applied to them: firstly, system theory itself provides a major obstacle by employing relatively idiosyncratic terminology and alienating concepts such as "autopoiesis" (Varela et al. 1974), "recursivity," or "emergence." While system theory has spread some marks throughout scientific terminology, e.g. we refer to ecological or political "systems," this often does not go beyond the mere usage of the term "system" without further acknowledging the ambitious theoretical programme associated with it. Secondly, a systemic approach is inevitably complex and, therefore, naturally adverse to specialization and expertise in a distinct field. Thirdly, system theory's critics complain about the vagueness of the concept; the uncertainty, or arbitrariness in defining the line between system and environment, and the inherent conservatism of a theory dealing with structures and patterns, thus not leaving much room for action, active revolution, or at least change. 
For all the above reasons, system theory has never succeeded as a widely accepted theoretical framework for the analysis of complex realities. Regardless of the correctness of these denouncements, there are two good reasons for a renewed interest in systemic thinking with respect to water issues: their complexity is undebatable and despite great efforts utilizing single disciplines, political and technical approaches, water related problems are persistent and will probably grow into one of the most challenging problems for the third millennium without coming close to any substantial and sustainable solution. Both reasons render it worthwhile to test the application of system theory's findings on the subject matter.

\subsection{The Governance Approach}

Governance has advanced to be one of the most popular concepts in the last two decades and thus the utilization of the governance discourse has also ousted the concept of water management (e.g. GWP 2003; Lebel et al. 2007; Bakker 2010; OECD 2011; Anne 2012; Perkins 2013). On the one hand, the popularity of the concept can well be explained by the widely shared expectation that governance enhances civil society's participation in making decisions and is more efficient at solving problems than governmental approaches. On the other hand, "governance" remains a highly amorphous notion and its promises still await empirical proof. Despite its widespread use, there is neither a shared definition of governance nor solid evaluations of governance practices. ${ }^{1}$ There is some agreement though that governance involves all sorts of regulations irrespective of whether they have been created intentionally or not, of their source, and of their success. The governance discourse thus shifts the perspective from deliberate, hierarchical, and goal-oriented exercise of political control by a government to the far more ambiguous processes of regulatory and evolutionary (self-) governing. Leaving aside the conceptual and normative deficits of the concept,$^{2}$ governance may serve as a rough pattern for a new assessment of water issues, pointing "on the one hand [...] to the complex setting of water management in wider governance structures that have to be accounted when assessing water usage. On the other hand, it points to the necessity of good governance - rule of law, stakeholder participation, transparency, accountability, etc. - in the water sector" (Sehring 2009, p. 17f.) Summed up, water governance encompasses all the actions, regulations, subjects, objects, and goals, which are involved in order to guarantee sustainable access to water for everyone and for all purposes (see Huitema et al. 2009). It also points out the impact and relevance of institutions, i.e. explicit and implicit norms and rules, which shape patterns of behavior and often severely influence how apparently just technical or ecological realities are dealt with by humans.

\footnotetext{
${ }^{1}$ As examples of positive expectations see Hauff (1987), Deutscher Bundestag (2002), for critique see e.g. Dingwerth (2003), Brand et al. (2000), Brand and Scherrer (2003).

${ }^{2}$ See out of innumerous: Benz (2004), Dobner (2010), Mayntz (2005), Folke-Schuppert (2006).
} 
There are four key guidelines of special interest in the literature on water governance, namely "polycentric governance, public participation, experimentation, and a bioregional approach" (Huitema et al. 2009) Polycentric governance relates to systems in which "political authority is dispersed to separately constituted bodies with overlapping jurisdictions that do not stand in hierarchical relationship to each other" (Skelcher 2005, p. 85, also Ostrom (1999), Dietz et al. (2003). Public participation stands for the cooperation between non-governmental stakeholders and governmental bodies. Experimentation is the demand to invent new practices and institutions and evaluate their potential for transfer to other problems, regions, or contexts. The bioregional approach finds its most prominent interpretation in the water sector in the call for river basin management. While all of these findings can be considered theoretically sound, unfortunately there is little known about their effectiveness so far: polycentricity and the bioregional approach have scarcely been evaluated because of "the lack of monitoring data and the attribution problem," participation "can contribute to the quality and legitimacy of decisions, but the connection to the formal decision process needs to be clearly specified" and about experimentation there is "not much known, but in other policy domains, experiments are often watered down to "pilots"” (Huitema et al. 2009).

\subsection{Dealing with Complexity}

System theory and the governance discourse both raise awareness that complex systems such as MWEPs must rely on a multifaceted analysis of interacting elements. By emphasizing the interrelatedness of different issues, they both underline the necessity to overcome fragmented scientific perspectives on and isolated responsibilities for MWEPs. Their potential benefits direct research and practice in two different, but complementary ways: system theory provides potential cornerstones for an analytic framework to address the complexity of MWEPs, and the governance discourse stresses the need to adhere to practical management issues.

From a systemic perspective, MWEPs are but one example in the generalized concept of systems, and thus opens the way for transferring general insights about systems to this specific field. Taking up the selected list mentioned above: the complexity of MWEPs can be interpreted as the need to take the mutual interdependence of historic, technical, political, social, and so forth aspects of an MWEP into account in the estimation of its feasibility, durance, robustness, and sustainability. Going one step further, MWEPs can be considered as examples of disorganized complexity, i.e. a system "in which the number of variables is very large, and one in which each of the many variables has a behaviour which is individually erratic, or perhaps totally unknown" (Weaver 1948). Therefore, a MWEP's management depends on the knowledge and consideration of all its influencing factors, rendering any hierarchy counterproductive in the sense of which elements are more or less important.

This aspect challenges especially technocratic approaches: MWEPs may be technically well thought out and can be perfectly infrastructural or materially 
organized, but they still can fail because of social or political rejection. All existing and future infrastructures and institutions have to be established against or before the background of former decisions and institutions. The role of history therefore cannot be overestimated in its effect of how things work out. The strong political, technical, and financial support, e.g. for the irrigation systems; the leading technicians and organizations; and the dominant role cotton played in the Fergana Valley during Soviet times were all demonstrations of economic strength. Economic strength then was a currency for inner and outer legitimacy of both communism in general, and of the political Soviet Union system in particular. For good or bad, the leftovers of the former water technocracy are still highly influential on the performance and stability of the water sector nowadays. On the one hand, the remaining organizational structures and personal connections are a guaranteeing factor, possibly the only one, for the survival of the technical functionality of the complex irrigation system. On the other hand, the remaining structures are a severe obstacle for institutional reforms such as establishing water pricing, land ownership, or individual agricultural decisions. The soviet legacy is therefore an important factor in the persistence of viable institutions as well as being a severe hindrance to institutional change. Historical institutions must also be seen as a background for newer political decisions: the agricultural output of the Fergana Valley counts for $20 \%$ of the state income of sovereign Uzbekistan, thereby relying on a system of water distribution which was stable only under the conditions of the former political union with Kyrgyzstan (which by now has other things in mind with the water desperately needed downstream for agriculture) and the agricultural system of a planned economy. Sustainable agricultural production was for ecological reasons - foremost the mismatch between water availability in the valley itself and the water greed of cotton - never achievable, and is unlikely in the future. Political decisions, of course, are intertwined with financial and economic aspects. As far as the new post-soviet economy is built on the ruins of an unsustainable agronomic revolution, it will be in the way of any capitalistic reform. But the intervention of capitalism, on the other hand, is one of leading demands of international donors such as the World Bank. Given the fact that former agricultural arrangements and the leftovers of soviet technology are the backbone of domestic economic income, any international intervention is doomed to be nothing other than a mock capitalist economy, severely hindered by soviet organizational and staffing structures and ideologies of the former republic.

Equally complex is the multifaceted context of the Red Sea - Dead Sea Project (RSDS). While it is certain that the shrinkage of the Dead Sea is severely impacting the surrounding landscape and seashore, the groundwater with salinization and depletion, and the economy and ecology of all riparian states; so far there are no agreements on the ecological and political outcomes of the project. Some promoters believe the technical feasibilities, others the goals - increasing and stabilizing water and power supply - are not realistic, nor are the potential damages to the environment foreseeable. Since the intervention is to take place in a highly variable climatological, hydrological, and geological surrounding, many factors should be taken into account, but there can be no certainty that the scientific models will provide an 
entirely complete picture of the consequences. Moreover, the potential benefits of the project would be unevenly distributed among the riparian states, thus increasing the danger of political turmoil, already one the most severe problems of the region. In the past lack of political agreement has already led to an underdevelopment of regulatory means: existing treaties are often ambiguous and weak when it comes to compliance control, adaption, and dispute settlement, and there is a little hope that the shortcomings of todays' regulations can be overcome within the framework of the ambitious new MWEP. It is obvious that to successfully achieve the set goals, if this is possible at all, very much depends on intervention that takes political, ecological, and social factors as much into account as the technical aspects of the endeavor.

This idea that, in general, systems operate within an environment draws our attention to another important factor of MWEPs: given that 263 of all river basins and more than 300 aquifers worldwide are transnational (UN-Water 2008), the operation of MWEPs is often placed in contexts where all variables are not under the control of their management/operational teams. In case of the Fergana Valley, it is very clear that the Kyrgyz government and the needs of the Kyrgyz economy are not under control of the Uzbek bodies running the irrigation system in the valley, yet their influence on time and amount of water flow has major influence on the system. In the RSDS case, one its leading characteristics is political hostility fuelled by scarcity of available space and ecological resources for growing populations in the riparian states which have little in common but a violent history and mutual distrust.

With their emphasis on polycentricity, public participation, a bioregional approach, and experimentation, governance literature and system theory both point to relevant factors beyond technical management. Dispersing institutional responsibility, ensuring participation, cooperating with neighboring states, and benefiting from experiments are hardly compatible with autocratic political environments. Indeed, all these findings from water governance literature call for a far more ambitious programme than just simply managing the technology of MWEPs; their call is for MWEPs to be embedded into democratic political environments.

Taking both approaches into account, the evaluation of MWEPs raises the following questions:

- Which relevant political, social, technical, economic, ecological, and international factors need to be taken into account in order to evaluate the implementation and maintenance of a MWEP?

- What is the constitutional setting into which the MWEP will be implemented?

- Who takes part in decision making about the implementation and management of a MWEP? Are all shareholders involved and do they have an equal share in the decision-making progress?

- What are the political relations with neighboring states like in general? Are there legal means to resolve conflicts? Which established institutions are there to manage transboundary issues associated with the project?

- Are there means to evaluate different approaches and identify good practices? Can they be transferred to, and how can they be adapted to another environment? Are local specifics taken into account in the transfer? 
Technical solutions for water issues rely on political and institutional designs, which encourage individuals and personal networks to work in favor of them. No great technology - not even one which is well engineered - can fulfill its purposes satisfactorily if it is not supported and sustained by people and institutions. A systemic view helps to understand the interrelatedness of ecological needs, patterns of behavior, political and regulatory institutions, historical legacies, and economic and technological features. The governance perspective points to the necessity to create regulatory means which can address the complexity of motives both of individuals and collectives. Institutional thinking underlines the fact that immaterial rules and norms eventually materialize.

Open Access This chapter is distributed under the terms of the Creative Commons Attribution Noncommercial License, which permits any noncommercial use, distribution, and reproduction in any medium, provided the original author(s) and source are credited.

\section{References}

Anne I (2012) Water governance - challenges in Africa. Hydro-optimism or hydro-pessimism? Peter Lang, Bern/Berlin/Bruxelles

Bakker K (2010) Privatizing water. Governance failure and world's urban water crisis. Cornell University Press, Ithaca

Benz A (ed) (2004) Governance - Regieren in komplexen Regelsystemen. Eine Einführung. VS Verlag für Sozialwissenschaften, Wiesbaden

Brand U, Scherrer C (2003) Contested global governance. Konkurrierende Formen und Inhalte globaler Regulierung. Kurswechsel, Zeitschrift für gesellschafts-, wirtschafts-, und umweltpolitische Alternativen 1:90-103

Brand U, Brunnengräber A, Schrader L et al (2000) Global governance. Alternative zur neoliberalen Globalisierung. Westfälisches Dampfboot, Münster

Bundestag D (ed) (2002) Schlussbericht der Enquete-Kommission. Globalisierung der Weltwirtschaft - Herausforderungen und Antworten. Leske + Budrich, Opladen

Dietz T, Ostrom E, Stern PC (2003) The struggle to govern the commons. Science 302:1907-1912. doi:10.1126/science.1091015

Dingwerth K (2003) Globale Politiknetzwerke und ihre demokratische Legitimation: Analyse der World Commission on Dams. Global Governance Working Paper No. 6. www.glogov.org. Accessed 10 Apr 2015

Dobner P (2010) Wasserpolitik: Zur politischen Theorie, Praxis und Kritik globaler Governance. Suhrkamp, Frankfurt am Main

Easton D (1957) An approach to the analysis of political systems. World Polit 9:383-400. doi: $10.2307 / 2008920$

Easton D (1965) A systems analysis of political life. Wiley, New York

Folke-Schuppert G (2006) Governance-Forschung. Vergewisserung über Stand und Entwickungslinien, 2nd edn. Nomos, Baden-Baden

GWP (2003) Effective water governance: learning from the dialogues. Global Water Partnership, Stockholm

Hauff V (1987) Unsere gemeinsame Zukunft: Der Brundtland-Bericht der Weltkommission für Umwelt und Entwicklung. Eggenkamp Verlag, Greven

Hill W, Fehlbaum R, Ulrich P (1994) Organisationslehre 1: Ziele, Instrumente und Bedingungen der Organisation sozialer Systeme, 5th edn. UTP, Stuttgart 
Huitema D, Mostert E, Egas W et al (2009) Adaptive water governance: assessing the institutional prescriptions of adaptive (co-)management from a governance perspective and defining a research agenda. Ecol Soc 14:26

Lebel L, Dore J, Daniel R, Koma YS (eds) (2007) Democratizing water governance in the Mekong region. Mekong Press, Chiang Mai

Mayntz R (2005) Governance Theory als fortentwickelte Steuerungstheorie? In: Folke-Schuppert G (ed) Governance-Forschung. Vergewisserung über Stand und Entwicklungslinien. Nomos, Baden-Baden, pp 11-20

Moss T, Dobner P (2015) Between multiple transformations and systemic path dependencies. In: Huettl RF, Bens O, Bismuth C, Hoechstetter S (eds) Society - water - technology: a critical appraisal of major water engineering projects. Springer, Dordrecht, pp 101-111

OECD (2011) Water governance in OECD countries: a multi-level approach. OECD Publishing, Paris

Ostrom E (1999) Die Verfassung der Allmende. Jenseits von Staat und Markt. Mohr Siebeck, Tübingen

Perkins P (ed) (2013) Water and climate change in Africa. Challenges and community initiatives in Durban, Maputo and Nairobi. Routledge, Oxon/New York

Sehring J (2009) The Politics of water institutional reform in neo-patrimonial states: a comparative analysis of Kyrgyzstan and Tajikistan. VS Verlag für Sozialwissenschaften, Wiesbaden

Skelcher C (2005) Jurisdictional integrity, polycentrism, and the design of democratic governance. Governance 18:89-110. doi:10.1111/j.1468-0491.2004.00267.x

United Nations (2006) The millennium development goals report 2006. United Nations, New York

United Nations (2007) The millennium development goals report 2007. United Nations, New York

United Nations (2008) Millenniums-Entwicklungsziele. Bericht 2008. United Nations, New York

United Nations (2009) The millennium development goals report 2009. United Nations, New York

United Nations (2012) The millennium development goals report 2012. United Nations, New York

UN-Water (2008) Transboundary waters: sharing benefits, sharing responsibilities. UN-Water, Geneva

Varela FG, Maturana RH, Uribe R (1974) Autopoiesis: the organization of living systems, its characterization and a model. Biosystems 5:187-196. doi: 10.1016/0303-2647(74)90031-8

von Bertalanffy L (1950) An outline of general system theory. Br J Philos Sci 1:134-165. doi:10.1093/bjps/I.2.134

Weaver W (1948) Science and complexity. Am Sci 36:536-544

Wiener N (1948) Cybernetics of control and communication in the animal and the machine. Herman Editions, Paris 